\title{
Workplace Mobbing: The Causal Factor of Neurotic Personality and Employees' Intention to Leave of Selected Private Institutions in South-West, Nigeria.
}

\author{
Adeoye, Solomon. O. \\ Egbuta, Olive. U. \\ Abolarin, Emmanuel O. \\ School of Management Sciences \\ Department of Business Administration and Marketing \\ Babcock University \\ Ilishan-Remo, Ogun State, Nigeria.
}

\begin{abstract}
The survival of any organisation in the modern-day business depends on harmonious relationship among employees charged with the responsibility of achieving organisation objectives. The study examined the impact of workplace mobbing as causal factor of neurotic personality and employees' intention to leave in South-West, Nigeria. It made use of descriptive survey on the target population made up of lower and middle level non-academic staff of five selected private institutions of higher education in South-West Nigeria with the sample size of 322 respondents. The researchers used primary method of data collection through adapted questionnaire to elicit response on a likert scale coded with numerical values for ease of data analysis. Frequencies and descriptive statistics were used to make inference from data collected. The study found that workplace mobbing had a moderately high impact on neurotic personality and employees' intention to leave in South-West, Nigeria. It was established from the analysis that workplace mobbing fuelled neuroticism and employees' intention to leave in the selected private institutions of higher education across the areas of the study.
\end{abstract}

Keywords: employees' intention to leave, neurotic personality, organisational survival, mobbing, workplace

\section{Introduction}

As work appraisal is being measured by organisations to ensure career progression of workers, many employees accede to turnover intention prompted by neurotic conditions such as nervousness, low morale, and many other psychological problems bathed by workplace mobbing (Loveday, 2018). The weight of workplace mobbing has undoubtedly provoked employees in contending with different forms of psychological issues that cause them to contemplate quitting their current jobs (Isin, 2004). Survey conducted by Saratoga Institute (SI) among 60,000 employees in Malaysia maintained that eighty per cent account of intention to leave is related to neurotic experience infused by mobbing (Johar, Shah \& Bakar, 2013). The reflection is exposed in the United Kingdom Higher Education Sector's report where thirty-four per cent of European workers settled for fixed-sum/daily-paid contract employment. The implication is that this set of people is being denied certain employment rights and privileges (Koukiadaki, n.d.). While few scholars argued that mobbing at work determines intention to leave (Leymann, 2010; Verduyn\& Brans, 2012), others have disregarded the role mobbing played (Kahn, 1990; Leymann, 2012).

Divincova and Sivakova (2014), Elci, Eridilek, Alpkan \& Sener (2014), Ertureten, Cemalcilor and Aycan (2013), Nwobia and Aljohani (2017), Shallcross, Sheehan, Ramsay (2008), Pelit and Pelit (2014) as well as Yuksel and Tuncsiper (2011) investigated the effect of workplace mobbing as related to leadership style, organisational attitudes, dissatisfaction, employees' performance, organisational commitment, and organisational cynicism. The authors gave no attention to the effect of workplace mobbing on neuroticism. Meanwhile, the physical and psychological effects adduced to the phenomenon range from depressive mood, loss of self-esteem, underperformance, sleeplessness, early medical retirement and low performance among employees (Park \& Yang, 2017). Park and Yang (2017) attribute the effect to psychological impairment, aggression, hostility, disagreeableness, provocations and employees' intention to leave. Furthermore, the institutional survey conducted by Right Management (RM) among universities in Africa accounted for sixty-five per cent low performance due to physical and psychological problems (Nwobia \& Aljohani, 2017). 
The momentum gained by workplace mobbing among employees in Nigeria has persistently appeared in form of criticism, demeaning opinions, excessive work monitoring prior to appraisal exercise, unkind and hostile comment, exclusion and excessive use of disciplinary actions for solving managment problems (Oladapo \& Banks, 2013).

In the past three decades, there have been growing interests in the matters of personality and turnover of employees as exhibited by the works of Mowday and Spencer (1981). As an extension of the debate, this study investigates mobbing as it affects neuroticism among non-academic employees in selected private institutions of higher education in SouthWest, Nigeria. Treglown, Zivkov, Zarola and Furnhan (2018) found a negative relationship between workplace mobbing combined with other variables on psychological stability and psychiatric symptoms. Their findings are corroborated with Constantinescu (2014) who found inverse and negative effect of workplace mobbing on employees' psychological safety. Furthermore, in a work-related context, Sertyesilisik, Tezel, Giritli, and Vatansever (2016) found that employees who are victims of neuroticism experience significant accidents and greater dissatisfaction. Buck (2011) had earlier confirmed the position of Sertyesilisik et al. (2016) as he had found neuroticism being related to on-the-job accidents and eventual intention to quit the workplace. Also, Clarke and Robertson (2011) found negative emotions such as abhorrence, guilt, anger, clumsiness, fear and sadness significantly related to neuroticism. On the other hand, Van, Ang and Botero (2008) found that perceived neurotic personality is positively related to behavioural modification, attitudinal change and lifestyle choice. Observing this dichotomy among the authors' findings has necessitated the need for the researchers to hypothesize that workplace mobbing has no significant impact on neuroticism in selected private institutions of higher education in South-West, Nigeria.

\section{Literature Review}

\subsection{Workplace mobbing}

Leymann (2012) conceptualises workplace mobbing as ganging up of colleagues and/or superiors against an individual employee. Similar to Leymann's assertion, Harper (2013) defines workplace mobbing as group mistreatment with greater effects on employee's psychological well-being and career prospect. Gresham (2018) describes workplace mobbing as emotional abuse by a group of employees; the term which explains how a group of employees in a concerted fashion deal with another employee in a hostile manner. The actors can be colleagues, superiors, or subordinates. According to World Health Organisation (2015), the methods a group of employees use in mobbing a coemployee can be direct or indirect. These include covert actions such as isolation and avoidance.Sometimes it could be confrontational behaviours such as belittling, bullying and humiliating. The common strand is the unkindness of the acts, and the sense of harassment it brings on the targets, of which according to Malik (2015) affect employee's emotional and psychological well-being.

Workplace mobbing according to Divincova and Sivakova (2014), is manipulation, systematic humiliation, psychological terror, maneuvering and targeted stimulation of stress on employees. In Duffy and Sperry (2012) point of view, workplace mobbing is defined as emotional abuse masterminded to oppress and invade workers. Duffy and Sperry (2012), using informational concept, expand further that workplace mobbing is a hostile and unethical communication directed towards an individual in a systematic way. It is an emotional oppression that takes place through vertical-horizontal direction. It describes superior as the oppressor, having more aggressive attitude and ascribes more recognition and strength to the position of a superior, where the victim finds difficulty in approaching justice. Divincova and Sivakova (2014) describe workplace mobbing as an equivalent of persistent struggle that cannot be underestimated in matters of governance. Constantinescu (2014) conceptualises workplace mobbing as a systematic psychological harassment through intimidation, humiliation, discrediting, isolation and endangering emotional wellbeing as well as professional competence. It undermines safety and security in the workplace.

Khoo (2010) postulates that workplace mobbing is more frequent in the non-profit sector, education, military and medical industry. Invariably, workplace mobbing takes place predominantly in organisations where job positions are considered more secured. As highlighted by the European Agency for Safety and Health at Work (EASH, 2013), the root cause factors of workplace mobbing include failure in corporate culture, sudden change in organisational focus, volatility and job security, lack of satisfaction and bad relationships among peers, superiors and subordinates, stressful environment and conflict of interests. Further study associates the cause of workplace mobbing to personal characteristics and conflict among employees (Kondori, 2015), which leads to condition of stress and makes the targets vulnerable to physiological and psychological problems (Leymann, 2010). Leymann (2012), however, expands the concept by conceptualising the effects of workplace mobbing on the following factors: communication distortion, social contacts, personal reputation and occupational situation. According to Leymann (2012), silence, verbal threats, rejection, lack of interactions, isolation, ridicule, capitalizing on weaknesses and ill comment on appearance are products of mobbing. 
Sloan, Matyok, Schmitz and Short (2010) classify workplace mobbing into three categories namely; common targets, emotional impacts and physical impacts. The concept describes the common targets as employees that are most creative, ethical and competent in the workplace. The reason for mobbing such employees according to Sloan et al. (2010) is as a result of outstanding performance, which becomes threat to other employees. The after effect is lowers morale which greatly affect performance. It diminishes eagerness to seek help from colleagues when facing difficult tasks. Due to the intense sense of isolation, it causes apprehension. This does not employ any form of collective physical abuse of employees; but rather targeted largely on the victim's innermost self. This is why Safina and Podgornaya (2014) believe that mobbing can take such an emotional toll on its victims that it eventually results to physical health damage. The persistent pressure that mobbing provokes in targets make relaxation difficult at work or away from work and cause fatigue. Therefore, in the context of this study, workplace mobbing is defined as physical, psychological, and behavioural stress deliberately inflicted by a group of employees on a targeted employee. It can be further described as unreceptive and unprincipled message focused on single or minority group of employees at a regular interval.

\subsection{Neuroticism}

Neuroticism debates the adjustment against employees' emotional tendency to be calm and steady or worried and easily distressed (Nielsen \& Knardahi, 2015; Pervin, 1993). Employees with high level of neuroticism are more likely than the average person to experience emotional reactions such as anxiety, anger, jealousy, guilt and depression. Neuroticism is one of the Big Five higher-order personality traits in the study of management psychology. Similarly, it is defined as a condition or tendency to be moody and to experience such feelings as anxiety, worry, fear, anger, frustration, envy, jealousy, guilt, depressed mood, and loneliness (Zaidi, Wajid, Zaidi, Zaidi \& Zaidi, 2013). Likewise, Singh, Singh and Singh (2014) agree with the above definition while explaining the concept of neuroticism among employees. Singh et al. (2014) defines neurotic personality experience as negative emotions like anger, frustration and anxiety that prevent an employee from settling down on a job. On the other hand, Lebowitz (2016) describes neuroticism as personality that indicates negative traits, not with a factor of meanness or incompetence, but rather, one of confidence and being comfortable with oneself and others on the job. Meanwhile, further description by Lebowitz (2016) encompasses employees' emotional instability and general temper. It explains that employees who are highly neurotic are generally given to anxiety, sadness, worry, low self-esteem, highly temperamental or easily angered, and they tend to be self-conscious and unsure of themselves. Jeng and Teng (2008) define neuroticism as emotional instability that determines the degree to which an employee is anxious, temperamental and moody. Lebowitz (2016) corroborates Jeng and Teng (2008) definition as a trait that processes negative attributes, and this also corresponds with Johar, Shah and Bakar (2012) who describe neuroticism as a continuous measure between emotional adjustment and maladjustment. This explains that the negative emotions produced by neuroticism prolong work process, and employees are mostly depressed as groups and individual's logical thinking is hindered. Neurotic employees encounter different challenges in the workplace. They find difficulty in relationship formation, keeping friendship and taking advice (Mayende\&Musenze, 2014). Neurotic employees lack trust and nurture wrong perception of their work environment. They perceive failure from defensive angle and they see organisation as being unjust in an attempt to suppress information that borders on their psychological experience (Mayende \& Musenze, 2014).

According to Johar et al. (2012), two dimensions of neurotic personality exist among leaders in connection with employee self-esteem. First, is the impact of emotional personality and the second is the impact of irrational personality. Emotional personality is one of the personality traits that exist in neurotic personality. Studies by Baron and Neuman (1996) describe emotional personality as bias approaches in the conduct of workplace such as non-verbal attitudes. Out of the non-verbal attitudes are violent look, (for instance; stared hard, in-view opinion, pessimism, conditioned response), body language signal (anger, finger pointing, throwing objects), aggressive eye contact (staring, dirty look, snubbing, the silent treatment, physical gestures, violation of physical space, and slamming objects). Some examples of verbal attitude are waste words, anger, shouting, looking down, cheating, angry manner, mocking, lie, humiliating employees in public, physically injured, injuring, prohibiting, setting aside their feelings and thoughts of a person, and lack of friendship.

Irrational personality is also another reason the level of employee self-esteem is affected, as this gives rise to a significant loss of self-respect and confidence in them. Ghani, Rahman and Tang (2008) reflect that the prejudice inherent in the behaviour of a leader is quite extreme and absurd. Irrational personality therefore offers no regard to other workers as organisation owns the liberty to do what is on her favour without thinking about physical and emotional condition of workers. With regards to the discussion above, neuroticism can be defined as emotional and irrational behaviour capable of hindering the thoughts and flow of activities of employees in the workplace. Constantinescu (2014) discovered that workplace mobbing is positively significant to psychological safety. 
Ertureten, Cemalcilor and Aycan (2013) investigates the relationship of downward mobbing and organisation attitudes, and discovered that perceptions of downward mobbing is significant to job satisfaction, affective commitment, continuous commitment and turnover intention (Ertureten et al.2013). Ertureten et al. (2013) study also established that higher perception of mobbing is significantly related to lower job satisfaction and lower affective commitment, and this from the researcher's point of view is significantly related to imbalance emotions (neuroticism).

\subsection{Employees' Intention to Leave}

Turnover intention and intention to leave are interchangeably used in the literature (Balogun, Adefila \& Olowodunoye, 2013). When employees consider quitting their jobs, it is regarded as intention to leave the organisation (Omar, Anuar, Majid, \& Johari, 2012). Bongar (2007) describes employees' intention to leave as a behavioural response to mobbing. The assumption is that the moment employees begin to regard workplace as source of their problems; there is tendency that they develop reactions like negative job attitudes, lack of satisfaction, post-traumatic stress disorder (PTSD) which eventually may results to intention to leave the organisation. According to Matthias and Gouthier (2011) as well as Malik (2014), intention to leave is referred to as willingness of employee to leave his job when another opportunity presents itself.This may be due to lack of job satisfaction, motivation, psychological challenges, work-life balance and many others. Malik (2015) defines employee intention to leave as a coping method of dealing with threatening situations. Bothma and Roodt (2013) view employees' intention to leave as mere withdrawal reaction within the workplace that may not result to actual turnover. Corroboratively, employees' intention to leave is regarded as imprecise, in that, it only conveys behaviour of interest and not the actual behaviour, which can as well be referred to as turnover intention (Mxenge, Dywili \& Bazana, 2014). Correspondingly, Tuzun and Kalemci (2012) assert that employees' intention to leave is a predictor of real turnover. This is why Dash and Baruah (2013) viewed employees' intention to leave as most disadvantaged for organisation.

Further to expansion of the concept of turnover intention, Elci, Eridilek, Alpkan and Sener (2014) highlight three different dimensions to employees' intention to leave namely; psychological, sociological and economical intentions. Xiong, Ye, Wang (2017) holds similar concept by attributing the causes of employees' intention to leave to individual psychological factors that evolve from failure to fulfil employees' emotional demands. A breakdown or violation of these psychological contracts has significant impact on the employees' behaviour (Rayton \& Yalabik, 2014). Other than psychological causes, there are demographic or sociological causes in terms of age, gender, tenure, educational qualifications, and marital related challenges (Ongori, 2007).

Similarly, Robyn and Du-Preez (2013) maintain that intention to leave organisation hinge on the factors that influence employees' attraction and easiness of movement. They are based on three determining factors such as external environmental factors, individual demographic and personal characteristics, and organisational and work-related elements. Robyn and Du-Preez (2013) consider certain organisational factors such as job characteristics, personnel policies or the work environment as components of turnover intention. Kim (2005), Grissom, Nicholson-Crotty and Keiser (2012), and Dawley, Andrews and Bucklew (2008) suggest factors such as workload, promotion and supervisor support as determinants of employees intention to leave. Kim (2005), Grissom et al. (2012) and Dawley et. al. (2008) note that employees who are satisfied with the various aspects of their jobs and work environment have higher prospect to keep working for their organisation. Explicitly, the moderate workload, opportunities for promotion and optimum support from supervisor lead to lower turnover rates and positive effect on the organisation.

Robyn and Du-Preez (2013) highlight advantages of investigating employees' intention to leave and come up with the view that awareness of employees' intention to leave assists human resources manager to realise retention strategies and help organisation minimize employees' turnover. Mxenge, Dywili and Bazana (2014) as well noted that having knowledge of employees' intention to leave espouse organisations with effective and efficient strategy for managing employees' turnover. Efforts of Bakker and Demerouti (2008) to explain the concept of intention to leave the organisation produce credible and classical description as to why employees might decide to leave the organisation. The classical description is illustrated in the model of workplace resources requirements (JD-R) which offers a plausible explanation as to why individuals may choose to leave the organisation. In most studies that used the JD-R conceptual model, intention to leave organisation happens to be the result of the demands of workplace. This means that employees' intention to leave arises from the challenges posed through external and internal organisational conditions.

Therefore, from the researcher's conceptual point of view, employees' intention to leave is unmistaken willingness to quit the organisation. This is construed as the final option in preparation for final withdrawal from the workplace. 


\subsection{Reciprocity Theory Perspective of Workplace Mobbing and Employees Intention to Leave}

The proponent of reciprocity theory was Smith (1970). The theory is concerned with the perception or the nature of treatment employees receive in the workplace. The major assumption of the theory is based on the premise that employees feel distressed when they perceive mistreatment in the workplace. The theory posited that when employees fail to achieve equity and justice, they are hostile towards the organisation producing such behaviour. The theory further explained that employees reciprocate towards kind and unkind behaviour, and regards organisation that is providing and fulfilling psychological contract as possessing kind behaviour towards employees' growth. This opinion is consistent with Magee et al. (2017) who believed that employees are more committed and emotionally stable when psychological security is being provided.

\section{Methodology}

The study concentrated on the impact of workplace mobbing as determining factor of neurotic personality and employees' intention to leave in South-West, Nigeria. It made use of descriptive survey research design to draw inference from the target population of lower and middle level non-academic staff of five selected private institutions of higher education. Krejcie and Morgan (1970) formula was adopted in computing the sample size of the respondents estimated at 0.5 margin error of $95 \%$ confidence level. The total number of respondents from the selected private institutions of higher education fell within the range of 1500-2000, determining the sample size of 322 respondents. The researchers used primary method of data collection for the adapted questionnaire as formerly used by Faheem and Mahmud (2015). Average Variance Extract and Composite Reliability were used to ensure completion of construct validation as recommended and utilized by Yusoff (2011). A total of 322 copies of questionnaire were administered out of which 282 were properly completed and returned.Frequencies and descriptive statistics were presented. Responses were based on a likert scale coded with numerical values for ease of data analysis. The values assigned to the scale were $1=$ very low, $2=$ low, $3=$ moderately low, $4=$ moderately high, $5=$ high and $6=$ very high. Average mean scores of the respondents were interpreted as follows: 5.50-6.00 was interpreted as very high; any item with a mean falling between $4.50-5.49$ was interpreted as high. Also, any item with a mean between 3.50-4.49 was regarded as moderately high; any item with a mean of between 2.50-3.49 meant moderately low; item with a mean of 1.50-2.49 was considered low while any item with a mean between 0.50 -1.49 was considered very low. The standard deviation described the distribution of the response in relation to the mean. It provided an indication of how far the individual responses to each factor vary from the mean. A standard deviation of $>1$ meant a significant variance showing nonconsensus in the responses while a standard deviation of $<1$ showed there was no significant variance hence consensus in response.

\section{Findings and Discussion}

Table 1 provided details of descriptive analysis of responses on workplace mobbing. Using a six point likert scale, the questionnaire had 7 items with a scale ranging from 1 to 6. One (1) represented "very low" and six (6) represented "very high".

Table 1: Descriptive Statistics on workplace mobbing

\begin{tabular}{|c|c|c|c|c|c|c|c|c|}
\hline Description & Level a & reemen & icale of & & & & & $\Xi$ \\
\hline Workplace Mobbing & 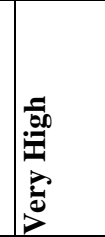 & 战 & 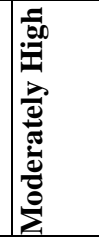 & 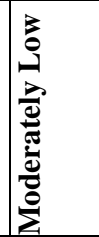 & 葛 & $\frac{3}{3}$ & $\sum_{\Sigma}^{\tilde{\varpi}}$ & 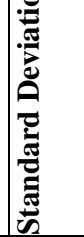 \\
\hline Group criticism & $1.1 \%$ & $37.4 \%$ & $44.0 \%$ & $10.1 \%$ & $5.5 \%$ & $1.9 \%$ & 4.130 & 0.950 \\
\hline Belittling opinions & $1.1 \%$ & $37.2 \%$ & $45.9 \%$ & $6.8 \%$ & $7.1 \%$ & $1.9 \%$ & 4.130 & 0.963 \\
\hline Close monitoring & $2.7 \%$ & $37.7 \%$ & $42.1 \%$ & $14.2 \%$ & $1.6 \%$ & $1.6 \%$ & 4.210 & 0.895 \\
\hline Public humiliation & $16.1 \%$ & $27.6 \%$ & $24.6 \%$ & $21.6 \%$ & $7.9 \%$ & $2.2 \%$ & 4.160 & 1.280 \\
\hline $\begin{array}{l}\text { Intimating the use } \\
\text { disciplinary procedures }\end{array}$ & $21.3 \%$ & $26.2 \%$ & $20.5 \%$ & $26.0 \%$ & $3.3 \%$ & $2.7 \%$ & 4.281 & 1.300 \\
\hline Exclusion & $17.2 \%$ & $18.3 \%$ & $25.4 \%$ & $31.1 \%$ & $7.1 \%$ & $0.8 \%$ & 4.050 & 1.242 \\
\hline \begin{tabular}{|lr}
$\begin{array}{l}\text { Unreasonable refusal } \\
\text { legitimate request }\end{array}$ \\
\end{tabular} & $16.7 \%$ & $11.5 \%$ & $26.0 \%$ & $35.2 \%$ & $8.5 \%$ & $2.2 \%$ & 3.861 & 1.290 \\
\hline Aggregate & & & & & & & 4.11 & 1.130 \\
\hline
\end{tabular}

Source: Researchers' Field Survey, 2019 
According to results in Table 1, 1.1\% of the respondents indicated that group criticism in their work place is very high, $37.4 \%$ indicated high, $44 \%$ moderately high, $10.1 \%$ moderately low, $5.5 \%$ low and $1.9 \%$ very low. On the average, the respondents indicated that group criticism is moderately high with a mean of 4.130 and standard deviation of 0.950 . Results also indicated that $1.1 \%$ of the respondents responded very high to belittling opinions, $37.2 \%$ indicated high, 45.9\% moderately high, $6.8 \%$ moderately low, $7.1 \%$ indicated low and $1.9 \%$ very low. On average, the respondents indicated that belittling opinions is moderately high with a mean of 4.130 and standard deviation of 0.963 .

Also $2.7 \%$ of the respondents indicated that close monitoring in the workplace is very high, $37.7 \%$ indicated high, $42.1 \%$ moderately high, $14.2 \%$ moderately low, $1.6 \%$ low and $1.6 \%$ very low. On average, the respondents indicated that close monitoring is moderately high with a mean of 4.210 and standard deviation of 0.895 . Results also indicated that $16.1 \%$ of the respondents responded very high to Public humiliation, $27.6 \%$ indicated high, $24.6 \%$ moderately high, $21.6 \%$ moderately low, $7.9 \%$ indicated low and $2.2 \%$ very low. On average, the respondents indicated that public humiliation is moderately high with a mean of 4.160 and standard deviation of 1.280 . Also $21.3 \%$ of the respondents indicated that intimating the use of disciplinary procedures in their workplace is very high, $26.2 \%$ indicated high, $20.5 \%$ moderately high, $26 \%$ moderately low, $3.3 \%$ low and $2.7 \%$ very low. On average, the respondents indicated that intimating the use of disciplinary procedures is moderately high with a mean of 4.281 and standard deviation of 1.300. Also $17.2 \%$ of the respondents indicated that exclusion in their workplace is very high, $18.3 \%$ indicated high, $25.4 \%$ moderately high, $31.1 \%$ moderately low, $7.1 \%$ low and $0.8 \%$ very low. On average, the respondents indicated that exclusion is moderately high with a mean of 4.050 and standard deviation of 1.242. Last item on the table shows that $16.7 \%$ of the respondents indicated that unreasonable refusal of legitimate request in their workplace is very high, $11.5 \%$ indicated high, $26 \%$ moderately high, $35.2 \%$ moderately low, $8.5 \%$ low and $2.2 \%$ very low. On average, the respondents indicated that unreasonable refusal of legitimate request is moderately high with a mean of 3.861 and standard deviation of 1.270. The grand mean for Workplace Mobbing is 4.11 with standard deviation of 1.130, indicating that Workplace Mobbing of the selected private institutions of higher education is moderately high.

Previous study on expatriate withdrawal cognitions on role of perceived work constraints and non-work constraints (Bader, Reade and Froese, 2016) found that perceived threat and related stress increased emotional constraints and propelled employees' intention to leave. Bader, et al. (2016) discovered that mobbing has indirect costs related to withdrawal cognitions among expatriates. This outcome is related to the findings of Howie (2014) in the investigation of threat to workplace relations. Even though the study (Howie, 2009) proved inadequate in comprehending the nature of threat and how emotional attack of employee affects intention to leave, the earlier study of Howie (2007) on threat and managing workplace found that threat to employees increased occupational stress and resulted to employees' intention to leave organisation. Related study by Aytac, Dursun and Akalp (2016) discovered that employees experienced high degree of job stress as job stressors affected the general physical health.This is further supported by Tillman, Hood, Richard (2017) who found underrating and belittling of subordinates as threats that increased employees fear and anxieties. Tillman et al. (2017) has a similar result compared to Jenneskens (2017) who also found that fear is positively significant to organisational growth. This is because it offers reduction in loyalty to organisation, increase in employment search and employees' intentions to leave.

In Table 2, respondents were asked to indicate their level of agreement with statements on neuroticism. Percentages, Mean Scores and Standard Deviation were computed for each statement. The findings were presented accordingly.

Table 2: Descriptive Statistics on neuroticism

\begin{tabular}{|c|c|c|c|c|c|c|c|c|}
\hline Description & Level of $\mathrm{A}$ & eement in $\mathrm{s}$ & e of 1-6 & & & & & \\
\hline Neuroticism & 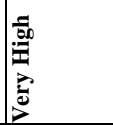 & 흠 & 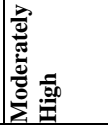 & 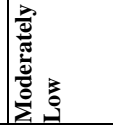 & 害 & $\frac{1}{3}$ & 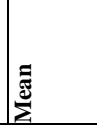 & 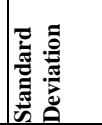 \\
\hline Early medical retirement & $0.5 \%$ & $30.3 \%$ & $51.1 \%$ & $11.2 \%$ & $4.6 \%$ & $2.2 \%$ & 4.04 & 0.905 \\
\hline Depressive mood among employees & $0.0 \%$ & $30.1 \%$ & $53.0 \%$ & $10.1 \%$ & $3.8 \%$ & $3.0 \%$ & 4.03 & 0.909 \\
\hline Loss of self-esteem & $3.3 \%$ & $27.3 \%$ & $44.5 \%$ & $18.0 \%$ & $4.6 \%$ & $1.9 \%$ & 3.99 & 0.994 \\
\hline Anxiety & $13.7 \%$ & $31.1 \%$ & $25.1 \%$ & $22.4 \%$ & $5.5 \%$ & $2.2 \%$ & 4.18 & 1.211 \\
\hline Underperformance & $17.2 \%$ & $28.4 \%$ & $21.9 \%$ & $23.2 \%$ & $6.6 \%$ & $2.7 \%$ & 4.18 & 1.297 \\
\hline Sleeplessness & $15.0 \%$ & $25.1 \%$ & $20.8 \%$ & $28.7 \%$ & $7.7 \%$ & $2.7 \%$ & 4.03 & 1.301 \\
\hline Loss of confidence & $17.8 \%$ & $12.6 \%$ & $22.7 \%$ & $33.6 \%$ & $10.4 \%$ & $3.0 \%$ & 3.84 & 1.356 \\
\hline \begin{tabular}{|l|} 
Aggregate \\
\end{tabular} & & & & & & & 4.050 & 0.954 \\
\hline
\end{tabular}

Source: Researchers' Field Survey, 2019 
Table 2 showed the respondents' opinion on neuroticism. As indicated in the Table, $0.5 \%$ respondents indicated very high as regards to early medical retirement, $30.3 \%$ indicated high, $51.1 \%$ indicated moderately high, $11.2 \%$ indicated moderately low, $4.6 \%$ indicated low and $2.2 \%$ indicated very low. On average, the respondents indicated that early medical retirement is moderately high with a mean of 4.04 and a standard deviation of 0.905 . Result revealed that $30.1 \%$ respondents indicated high as regards to depressive mood among employees, $53.0 \%$ indicated moderately high, $10.1 \%$ indicated moderately low while $3.8 \%$ indicated low and 3.0\% indicated very low. On the average, the respondents indicated that depressive mood among employees is moderately high with a mean of 4.03 and a standard deviation of 0.909 .

As regards the loss of self-esteem, 3.3\% respondents indicated very high, $27.3 \%$ indicated high, $44.5 \%$ indicated moderately high, $18 \%$ indicated moderately low, while $4.6 \%$ indicated low and $1.9 \%$ indicated very low. On the average, the respondents indicated that loss of self-esteem is moderately high with a mean of 3.99 and a standard deviation of 0.994 . With respect to anxiety, $13.7 \%$ respondents indicated very high, $31.1 \%$ indicated high, $25.1 \%$ indicated moderately high, $22.4 \%$ indicated moderately low, while $5.5 \%$ indicated low and $2.2 \%$ indicated very low. On the average, the respondents indicated that anxiety is moderately high with a mean of 4.18 and a standard deviation of 1.211 . Moreover, $17.2 \%$ of the respondents indicated very high to Underperformance, $28.4 \%$ indicated high, $21.9 \%$ indicated moderately high, $23.2 \%$ indicated moderately low while $6.6 \%$ indicated low and $2.7 \%$ indicated very low. On the average, the respondents indicated that underperformance is moderately high with a mean of 4.18 and a standard deviation of 1.297 .

Regarding sleeplessness, 15\% respondents indicated very high, $25.1 \%$ indicated high, $20.8 \%$ indicated moderately high, $28.7 \%$ indicated moderately low, while $7.7 \%$ indicated low, and $2.7 \%$ indicated very low. On the average, the respondents indicated that sleeplessness is moderately high with a mean of 4.03 and a standard mean of 1.301. Lastly $17.8 \%$ respondents indicated very high as regards to loss of confidence, $12.6 \%$ indicated high, $22.7 \%$ indicated moderately high, $33.6 \%$ indicated moderately high while $10.4 \%$ indicated low and $3.0 \%$ indicated very low. On average of the respondents indicated that loss of confidence is moderately high with a mean of 3.84 and a standard deviation of 1.356. The grand mean for neuroticism is 4.050 with standard deviation of 0.954 , indicating that neuroticism in selected private institutions of higher education in South-West Nigeriais moderately high.

The finding is in agreement with Ertureten et al.(2013),Yuksel and Tuncsiper (2011) confirmed a positive relationship between mobbing and organisational commitment.Yuksel and Tuncsiper (2011) discovered positive relationship between mobbing, organisational commitment and affective commitment. Since employees' affective commitment represents emotional bond that determines employee's dedication and loyalty to the organisation, it can be said that those employees who experience imbalance emotion (neurotic) will unlikely be dedicated to the organisation but rather nurture intention to leave. This is in contrast to the findings of Pelit and Pelit (2014) while examining the effect of mobbing perception on organisational Cynicism in Turkey. Pelit and Pelit (2014) resolved on significant relationship between mobbing perceptions and organisational cynicism. The researcher distilled that if cynicism shares the idea of pessimism just like neuroticism portrays imbalance or negative emotions, then workplace mobbing is significant to neuroticism.

In relational context, studies had found that employees who experience negative emotions like hatred, guilt, anger, clumsiness, fear and sadness are victims of neuroticism. Clarke and Robertson (2011) discovered significant relationship between neurotic employees and mobbing, depression, anger and insecurity. In a work-related context, Sertyesilisik, Tezel, Giritli, and Vatansever (2016) noted that employees who are victims of neuroticism experience significant more accidents and greater dissatisfaction at work. Buck (2011) confirmed this as he concluded that neuroticism is a significant predictor of accidents at work and employees intention to quite. Meanwhile, Smith, Moss and Dyer (2016) had earlier opposed these findings stating that neuroticism has the strongest and direct prediction of affective elements of indecision in the workplace. In support, Joseph, Jin, Newman and O'Boyle (2016) and Vance (2016) established that there is no significant relationship between neuroticism, job performance and safety behaviour in the workplace. With this, the researcher is not left without assurance that workplace mobbing is significant to employees intention to leave, just as Kondori (2015) concluded that workplace mobbingis positively significant to employees safety and work performance. Consistent with Kondori (2015)'s finding is the study ofJaksic, Brajkovic, Ivezic, Topic and Jakovljevic (2012) who discovered that in-conducive work climate is positively related to neuroticism.

According to Nielsen and Knardahi (2015), mobbing affect the personality traits of victims. Nielsen et al. (2015) has a close link with Pallesen, Nielsen, Mageroy, Andreassen and Einarsen (2017) who posited that mobbing is positively related to neuroticism and extraversion, and inversely related to openness, agreeableness and conscientiousness. To buttress these findings, Mitsopoulou and Giovazolias (2015) found significant relationship between workplace 
mobbing and changes in personality. This is congruent to the earlier study of National Academy of Science (2003) on array of personality individualities. National Academy of Science (2003) study showed that there is a significant relationship between mobbing, psychological reactions and psychiatric symptoms in employees.

\section{Conclusion}

The study surveyed workplace mobbing, neuroticism and employees intention to leave in selected private institutions of higher education in South-West Nigeria. It settled on the impact of workplace mobbing as causal factor of neurotic personality and employees' intention to leave. The result drew out statistical evidences to show that neuroticism and employees' intention to leave in South-West Nigeria are moderately high as occasioned by workplace mobbing. This showed that, aside many other factors, workplace mobbing is a unilateral determinant of neuroticism and employees' intention to leave inselected private institutions of higher education in South-West Nigeria. To prevent this ugly trend therefore, it is imperative for organisation to show concern and give adequate care to the psychological state of mind of employees. It is indeed important also for organisation to focus on productivity hinged on holistic employees' welfare which projects the culture of a friendly and peaceful co-existence and consolidates employees' sense of security, safety and self-worth within the workplace.

\section{Future Scope}

Further studies can adopt regression method of data analysis to examine the impact of workplace mobbing on neurotic personality and employees intention to leave in public institutions of higher education of the region or beyond.

\section{References}

Aytac, S., Dursun, S., \& Akalp, G. (2016). Workplace violence and effects on turnover intention and job commitment: a pilot study among healthcare workers in turkey. European Scientific Journal, Special Edition, page 458-465.

Bader, A. K., Reader, C., \& Froese, F. J. (2016). Terrorism and expatriate withdrawal cognitions: The differential role of perceived work and non-work constraints. International Journal of Human Resources Management, 1-25.

Bakker, A. B., \&Demerouti, E. (2008). Towards a model of work engagement. Journal of Career Development International, 3(3), 209-223.

Balogun, A. G., Adefila, G. A., \& Olowodunoye, S. A. (2013). Job conditions, psychological climate and affective commitment as predictors of intention to quit among two groups of bank employees in Nigeria. Romanian Journal of Applied Psychology, 15(1), 9-19.

Baron, R., \& Neuman, J. H. (1996) Workplace violence and workplace aggression: Evidence concerning specific forms, potential causes, and preferred targets. Journal of Management, 24(3), 391-419.

Bongar, B. (2007). The psychology of terrorism: Defining the need and describing the goals. Breckenridges, Journals, $6(1), 147-154$.

Bothma, F. C., \& Roodt, G. (2013). The validation of the turnover intentions scale. SA Journal of Human Resource Management, 11(1),1-12.

Buck, M. A. (2011). Proactive Personality and big five traits in supervisors and workgroup members: Effects on safety climate and safety motivation. Portland: University Press..

Clarke, S., \& Robertson, I. T. (2011). A meta- analytic review of the Big Five personality factors and accident involvement in occupational and non-occupational settings. Journal of occupational and organisational psychology, 78(3),355-375.

Contantinescu, V. (2014). Mobbing: Psychological terror in the workplace. A Journal of Scientific Research and Education in Air-force, 2, 511-514.

Dash, B. L., \& Baruah, M. (2013). Employment retention: A review of literature. Journal of Business and management, 14(2), 8-16.

Dawley, D. D., Andrews, M. C., \& Bucklew, N. S. (2008). Mentoring supervisor support and perceived organisational support: what matters most? Leadership and Organisational Development Journal, 29(3), 235-247.

Divincova, A., \& Sivakova, B. (2014). Mobbing at workplace and its impact on employee performance. A Journal of Human Resources Management and Ergonomics, 8, 20-34.

Duffy, M., \& Sperry, L. (2012). Mobbing. New York: Oxford University Press. Page 305.

Elci, M., Eridilek, K., Alpkan, L., \&Sener, I. (2014). The mediating role of mobbing on the relationship between organisational silence and turnover intention. Journal of Procedia-social and Behavioural Sciences, 150, 455464.

Ertureten, A., Cemalcilor, Z., \&Aycan, Z. (2013). The relationship of downward mobbing with leadership style and organisational attitudes. Journal of Business Ethics, pg. 206. 
EASH (2013).The root cause of mobbing. European Agency for safety and health at work. Retrived from http://osha.europa.eu./en on February 10, 2018.

Faheem, M. A., \& Mahmud, N. (2015). The effects of organisational justice on workplace deviance and job satisfaction of employees: Evidence from a public sector hospital in Pakistan. Mediterranean Journal of Social Sciences, 6(5), 342-352.

Ghani, A., Rahman, H. A., \& Tang, K. N. (2008). Dimension of neuroticism personality among leaders and the impact towards self-esteem of employees in the workplace. Journal of Pendidikan,33(8), 47-60.

Gresham, T. (2018). What is mobbing at the workplace? Journal of Small Business, Advertising and Marketing. Hearst Newspaper, LLC.

Grissom, J. A., Nicholson-Crotty, J., \& Keiser, L. (2012). Does my boss gender matter? Explaining job satisfaction and employee turnover in the public sector. Journal of Public Administration Research and Theory, 22, 649673.

Harper, J. (2013). Surviving workplace mobbing: Identifying the stages.Psychology Today, Sussex Publishers, LLC.

Howei, L. (2007). The terrorism threat and managing workplaces. Journal of Prevention and Management, 16(1),7078.

Howie, L. (2009). The terrorism threat and managing workplace. Disaster prevention and management. An International Journal of Religious Tourism and Pilgrimage, 16(1),70-78.

Howie, L. (2014). Security guards and counter-terrorism: Tourism and gaps in terrorism prevention. International Journal of Religious Tourism and Pilgrimage, 2(1), 38-47.

Isin, E. F. (2004). The neurotic citizen. Journal of Citizenship Studies, 8(3), 217-235.

Jaksic, N., Brajkovic, L., Ivezic, E., Topic, R., \&Jakovljevic, M. (2012). The role of personality traits in posttraumatic stress disorder (PTSD). A Journal of Psychatria Danubina, 24(3), 256-266.

Jeng, S., \& Teng, C. I. (2008). Personality and motivations. An International Journal of Social Behaviour and Personality, 36(8),1-9.

Jenneskens, M. (2017). The relationship between employability and turnover intention: The moderating role of perceived organisational support and promotional opportunities. Bachelors Thesis, Tilburg University.

Johar, S. S., Shah, I. M., Bakar, Z. A. (2013). The impact of emotional intelligence towards relationship of personality and self-esteem at workplace. Journal of Social and Behavioural Sciences,65(12), 275-284.

Johar, S. S., Shah, I. M., Bakar, Z. A. (2012). Neuroticism personality and emotional intelligence of leader, and impact toward self-esteem of employee in organisation. Journal of Social and Behavioural Sciences,84(13),431-436.

Joseph, D. L., Jin, J., Newman, D. A., \& O'Boyle, E. H. (2016). Why does self-reported emotional intelligence predict job performance? A meta-analytic investigation of mixed El. Journal of Applied psychology, 10(2), 298-342.

Kahn, W. A. (1990), Psychological conditions of personal engagement and disengagement at work. Academy of Management Journal, 33(4),692-724.

Khoo, S. B. (2010). Academic mobbing: Hidden health hazard at workplace. Malaysian Family Physician Journal, $5(2), 61-67$.

Kim, S. (2005). Factors affecting state government information technology employees turnover intention. American Review of Public Administration Journal, 35(2),137-156.

Kondori, B. G. (2015). Mobbing and individual antecedents in commercial banks of North Cyprus. Gazimağusa, North Cyprus: Institute of Graduate Studies and Research, Eastern mediterranean University Press ,1-52.

Koukiadaki, A. (n.d.). The regulation of fixed-term work in Britains. University of Cambridge, 1-22.

Krejcie, R.V., \& Morgan, D. W. (1970). Determining sample size for research activities. Journal of Educational and Psychological measurement, 30, 607-610.

Lebowitz, S. (2016). The big five personality traits and five factors models. Article on Positive Psychology, 4-7.

Leymann, H. (2010). Mobbing in the library workplace: What it is and how to prevent it. Journal of Association of College and Research Libraries, 71(7), 2150-6698.

Leymann, H. (2010). The content and development of mobbing at work. European Journal of Work and Organisational Psychology, 5,165-184.

Leymann, H. (2012). Somatic and psychological symptoms after the experience of life threatening events. A profile analysis. Journal of Victimology, 10(14), 512-538.

Loveday, V. (2018). The neurotic academic casualization and governance in the neoliberalising University. Journal of Cultural Economy, 11(2), 154-166.

Magee, C., Gordon, R., Robinson, L., Caputi, P., \&Oades, L.G. (2017). Workplace bullying and absenteeism: the mediating roles of poor health and work engagement. Human Resource Management Journal, 27(3), 319-334.

Malik, O. F. (2014). The effects of terrorism on work attitudes and behaviours: A literature review and a proposed model. Journal of Aggression, Conflict and Peace Research, 6(3),143-163. 
Malik, O. F. (2015).Effects of terrorism fears on job attitudes and turnover intentions: The Moderating Role of Job Involvement pages. 2nd International Symposium on Partial Least Squares Path Modelling, Seville (Spain), 112.

Matthias, H. J., \&Gouthier, M. R. (2011). Organisational pride and its positive effects on employee behaviour. Journal of Science Management, 22(5), 633-649.

Mayende,T. S., \&Musenze, I. A. (2014). Personality dimensions and job turnover intentions: Findings from a University context. Journal of School of Postgraduate Studies and Research, Busoga University, Iganga Uganda.

Mitsopoulou, E., \&Giovazolias, T. (2015). Personality traits, empathy and bullying behaviour:A meta-analytic approach. Journal of Aggression and Violent Behaviour, 21(15), 61-72.

Mowday, R. T., \& Spencer, D. G. (1981). The influence of task and personality characteristics on employee turnover and absenteeism incidents. The Academy of Management Journal, 24 (3), 634-642.

Mxwenge, S.V., Dywili, M., Bazana, S. (2014). Job engagement and employees' intention to quit among administrative personnel at the University of Fort Hare in South Africa. International Journal of Research in Social Sciences,4(5),129-144.

Mxwenge, S.V., Dywili, M., \&Bazana, S. (2014). Organisational stress and employees intention to quit amongst administrative personnel at the University Of Fort Hare, Eastern Cape, South Africa. International Journal of Research in Social Science, 4(5),13-39.

National Academy of Science (2003). The range of terrorism events. 2101 constitution Avenue, N.W., Lockbox 285, Washington, D.C. National Academics Press.

Nielsen, M. B., \&Knardahi, S. (2015). Is workplace bullying related to the personality traits of victims? A two years prospective study. A Journal on Work and Stress, 29(2),128-149.

Nwobia, I. E., \&Aljohani, M. S. (2017). The effect of job dissatisfaction and workplace bullying on turnover intention: Organisation climate and group cohesion as moderators. International Journal of Marketing Studies, 9(3),136143.

Oladapo, V., \& Banks, L.T. (2013)Management Bullies: The Effect on Employees. Journal of Business Studies Quarterly, 4(4),107-120.

Omar, K., Anuar, M. M., Majid, A. H., \& Johari, H. (2012). Organisational commitment and intention to leave among nurses in Malaysian public hospital. International Journal of Business and Social Science, 3(16),194-199.

Ongori, H. (2007). A review of literature on employee turnover. African Journal of Business Management, 1(3), 49-54.

Pallesen, S., Nielsen, M. B., Mageroy, N., Andreassen,C. S., \& Einarsen, S. (2017). An experimental study on the attribution of personality traits to bullies and targets in a workplace setting. Journal of Frontiers in Psychology, 8(17), 1-7.

Park, K., \& Yang, T., (2017). The Long-term effect of self-esteem on regression: The roles of Alcohol and substance uses during young adulthood. Journal of National Library of Medicine and National Institute of Health, $58(3), 429-446$.

Pelit, E., \&Pelit, N. (2014). The effects of mobbing on organisational cynicism: A study of hotels in Turkey. International Journal of Human Resources Studies, 4(1), 34-56.

Pervin, L. A. (1993). Personality theory and research. $\left(6^{\text {th }}\right.$. ed). New York, NY. John Wiley \& Son.

Rayton, B. A., \& Yalabik, Z.Y. (2014). Work management, psychological contract breach and job satisfaction. The International Journal of Human Resource Management, 25(17), 1-19.

Robyn, A., \& Du-Preez, R. (2013). Intention to leave amongst generation Y academics in higher education. South African Journal of Industrial Psychology, 39(1),1-14.

Safina, D., \&Podgornaya, A. (2014). Mobbing as an organisational phenomenon impeding implementationof changes. Mediteranean Journal of Social Sciences, 5(18),187-192.

Sertyessilisik, B., Tezel, E., Giritli, H., \&Vantansever, N. (2016). An investigation into the relationship between personality and learning styles in construction industry: As a potential tool for improving health and safety performance. International Journal on Working Conditions, 12, 118-134.

Shallcross, L., Sheehan, M., \& Ramsay, S. (2008). Workplace mobbing: Experiences in the public sector. International Journal of Organisational Behaviour, 13(2),56-70.

Singh, A. K., Singh, A., \& Singh, A. P. (2014). Personality traits and turnover intention among front level managerial personnel. Journal of the Indian Academy of Applied Psychology, 40(2), 228-236.

Sloan, L., Matyok, T., Schmitz, C., \& Short, G. (2010). A story to tell: Bullying and Mobbing in the workplace. International Journal of Business and Social Science, 1(3), 87-97.

Smith, A. (1970). The Theory of Moral Sentiments, 6th edition. Ed. D.D. Raphael \& A.L. Macfie.Indianapolis: Liberty Fund, Inc. 
Smith, J., Moss, A. C., Dyer, K. R. (2016). Do baseline executive functions mediate prospective memory performance under a moderate dose of alcohol. Journal of Frontiers in Psychology,7(16),1-12.

Tillman, C. J., Hood, A. C., \& Richard, O. C. (2017). Supervisor- subordinate relationship conflict asymmetry and subordinate turnover intentions: the mediating roles of stress and counterproductive work behaviours. Journal of Behavioural and Applied Management, 17(3),169-196.

Treglown, L., Zivkov, K., Zarola, A., \& Furnhan, A. (2018). Intention to quit and the role of dark personality and perceived organisational support: a moderation and mediation model. Plos one A Peer Reviewed Open Assess Journal, 13(3),1-13.

Tuzun, I. K., \&Kalemci, R. A. (2012). Organisations and supervisory support in relation to employee turnover intentions. Journal of managerial psychology, 27(5), 518-534.

Van, D.L., Ang, S., \& Botero, I.C. (2008). Conceptualising employee silence and employee voice as multidimensional construct. Journal of management studies, 40(6),1359-1392.

Vance, D. L. (2016). The relationship between participative leadership styles and employee satisfaction with possible moderators of emotional stability (neuroticism) and years of experiences, Trevecca Nazarene University.

Verduyn, P., \&Brans, K. (2012). The relationship between extraversion, neuroticism and aspects of trait affect, Journal of Research in Personality, 50(14),11-22.

WHO (2015). World Health Stastistics. Retrieved from https://app. Who/int/iris/on March 25,2018.

Xiong, Z., Ye, J. \& Wang, P. (2017). Psychological contract and turnover intention of dispatched employees: Mediating effects of job satisfaction and organisational commitment. Working together, 56(17), 19-43.

Yusoff, M. S. (2011).A confirmatory factor analysis study on the medical student stressor questionnaire among Malaysian medical students. Education in Medicine Journal, 3(1),44-53.

Yuksel, M., \&Tuncsiper, B. (2011). The relationship between mobbing and organisational commitment in workplace. Journal of International Review of Management and Marketing, 1(3), 54-64.

Zaidi, N. R., Wajid, R. A., Zaidi, F. B., Zaidi, G. B., \& Zaidi, M.T. (2013). The big five personality traits and their relationship with work equipment among among Public Sector University teachers of Lahore. African Journal of Business Management, 7(15), 1353-1354. 